Rev. Int. Contam. Ambie. 33 (Especial Biotecnología e ingeniería ambiental) 33-42, 2017

DOI: 10.20937/RICA.2017.33.esp01.03

\title{
ORGANOCHLORINE PESTICIDE RESIDUES IN AGRICULTURAL SOILS FROM RÉGION DES PLATEAUX IN TOGO
}

\author{
Lankondjoa KOLANI ${ }^{2}$, Gbénonchi MAWUSSI ${ }^{2}$, Damien A. DEVAULT ${ }^{1 *}$ and Komla SANDA ${ }^{2}$
}

${ }^{1}$ Faculté de Pharmacie, Université Paris Sud. UMR 8079, CNRS, AgroParisTech, Université Paris-Saclay, France

${ }^{2}$ Unité de Recherche Sur les Agroressources et la Santé Environnementale, Ecole Supérieure d'Agronomie, Université de Lomé, BP. 1515, Lomé, Togo

*Corresponding author: damien.devault@martinique.univ-ag.fr

(Received October 2015; accepted August 2016)

Key words: west Africa, vegetable production, contamination

\begin{abstract}
Région des Plateaux in Togo is the highest producer of cash crops (coffee, cocoa, cotton) as well as vegetables. This region is the area with the supreme use of chemical pesticides to enhance agricultural production in Togo (west Africa). As effective as these chemicals may be in achieving this goal, the incidence of their residues on the environment, together with the associated adverse effects, have been of serious concerns. The objective of this study is to assess soils contamination by organochlorine pesticides in vegetable production areas within this region. Fifty-four soil samples were randomly collected from selected farmers' plots within six villages. The analytical methods included solvent extraction of pesticide residues and their subsequent quantification using gas chromatography - electron capture detector (GC-ECD). Twenty one different organochlorine pesticides were analyzed. The analytical results showed that only aldrin, endosulfan ( $\alpha-, \beta$ - and sulfate), and hexachlorocyclohexanes $(\mathrm{HCH})$ isomers, including $\alpha-\mathrm{HCH}, \beta-\mathrm{HCH}, \delta-\mathrm{HCH}$ and $\gamma-\mathrm{HCH}$ were detected in various concentrations. The residuals of aldrin varied from detection limit (DL) $(<0.001 \mu \mathrm{g} / \mathrm{kg})$ to $0.93 \pm 0.03 \mu \mathrm{g} / \mathrm{kg}$, the concentrations of $\alpha$-endosulfan from DL to $1.88 \pm 0.41 \mu \mathrm{g} / \mathrm{kg}$, $\beta$-endosulfan from DL to $0.4 \pm 0.01 \mu \mathrm{g} / \mathrm{kg}$ and endosulfan sulfate from DL to $3.87 \pm$ $0.19 \mu \mathrm{g} / \mathrm{kg}$. On the other hand the concentration of each isomer of $\mathrm{HCH}$ ranged from DL to $0.89 \pm 0.07 \mu \mathrm{g} / \mathrm{kg}(\alpha-\mathrm{HCH}), 14.6 \pm 0.12 \mu \mathrm{g} / \mathrm{kg}(\beta-\mathrm{HCH}), 4.27 \pm 0.61 \mu \mathrm{g} / \mathrm{kg}$ $(\gamma-\mathrm{HCH})$ and $2.92 \pm 0.05 \mu \mathrm{g} / \mathrm{kg}(\delta-\mathrm{HCH})$. The pesticide residue concentrations found in the studied soils were highly below maximum residue limits varying from 100 to $8000 \mu \mathrm{g} / \mathrm{kg}$ set by Food and Agriculture Organization of the United Nations (FAO). The detected pesticide residues reflected the type of pesticides that have been used in the study areas. The differences in the concentrations of these pesticide residues in the soil samples are likely the result of substantial inter-farm variation in intensive use of pesticide as well as the variation in their degradation dynamics. The findings of this study provide information on residue levels of organochlorine pesticides in soils from "Région des Plateaux" in Togo. Routine monitoring of pesticide residues in these study areas is necessary for the prevention, control and reduction of environmental pollution, leading to minimize health risks.
\end{abstract}

Palabras clave: oeste de África, producción vegetal, contaminación 


\section{RESUMEN}

La región "des Plateaux" en Togo es una de las más grandes productoras de cultivos comercials (café, cocoa, algodón), así como también de verduras. Esta región es el área con el mayor uso de pesticidas químicos para mejorar la producción de la agricultura en Togo (oeste de África). Así como son de efectivos estos químicos, la incidencia de sus residuos en el ambiente también lo es, al igual que los efectos adversos asociados a ellos, que se han convertido en un serio interés. El objetivo de este estudio es investigar la contaminación de suelos por pesticidas organoclorados en áreas de producción vegetal de esta región. Cuarenta y cuatro suelos fueron muestreados y colectados al azar desde parcelas seleccionadas por los agricultores en seis pueblos. Se utilizaron métodos analíticos, en los que se incluyeron la extracción de solventes provenientes de residuos de pesticidas y su subsecuente cuantificación por medio de cromatografía en fase gaseosa con detección por captura electrónica (GC-ECD). Se analizaron 21 diferentes pesticidas organoclorados. Los resultados analíticos mostraron que sólo la aldrina, el endosulfán y los isómeros de hexaclorociclohexanos $(\mathrm{HCH})$, incluyendo $\alpha-\mathrm{HCH}, \beta-\mathrm{HCH}, \delta-\mathrm{HCH}$ y $\gamma-\mathrm{HCH}$ fueron detectados en distintas concentraciones. Los residuos de aldrina variaron del límite de detección (LD) $(<0.001 \mu \mathrm{g} / \mathrm{kg}$ ) a $0.93 \pm 0.03 \mu \mathrm{g} / \mathrm{kg}$, las concentraciones de $\alpha$-endosulfan del LD a $1.88 \pm 0.41 \mu \mathrm{g} / \mathrm{kg}, \beta$-endosulfan del $\mathrm{LD}$ a $0.4 \pm 0.01 \mu \mathrm{g} / \mathrm{kg}$ y el sulfato de endosulfán del $\mathrm{LD}$ a $3.87 \pm 0.19 \mu \mathrm{g} / \mathrm{kg}$. Por otro lado, la concentración de cada isómero del HCH oscilaron desde el LD a $0.89 \pm$ $0.07 \mu \mathrm{g} / \mathrm{kg}(\alpha-\mathrm{HCH}), 14.6 \pm 0.12 \mu \mathrm{g} / \mathrm{kg}(\beta-\mathrm{HCH}), 4.27 \pm 0.61 \mu \mathrm{g} / \mathrm{kg}(\gamma-\mathrm{HCH})$ y $2.92 \pm 0.05 \mu \mathrm{g} / \mathrm{kg}$ $(\delta-\mathrm{HCH})$. Las concentraciones de los residuos de pesticida encontrados en los suelos estudiados estuvieron muy por arriba de los límites máximos indicados por la Organización de Alimentos y Agricultura de las Naciones Unidas (FAO), con valores desde $100 \mathrm{a} 8000 \mu \mathrm{g} / \mathrm{kg}$. Los residuos de pesticidas detectados reflejan el tipo de plaguicidas que se han utilizado en el sitio de estudio. Las diferencias en la concentración de estos residuos en las muestras de suelo son posiblemente el resultado de variaciones sustanciales entre cultivos con un uso intensivo de pesticidas, así como a la variación de su dinámica de degradación. Los hallazgos de este estudio proseen información sobre los niveles de residuos de pesticidas organoclorados en suelos de la región "des Plateaux" en Togo. El monitoreo frecuente de los residuos de pesticidas en estas áreas de estudio es necesario para la prevención, control y reducción de la contaminación ambiental, que a su vez minimizan los riesgos a la salud.

\section{INTRODUCTION}

Organochlorine pesticides (OCPs) are an important group of persistent organic pollutants (POPs) (UNEP 2001). They have a long historical use in the world to control agricultural pests as well as human and farm animal diseases. Since their introduction in the 1940s, they have improved crop yields (Willett et al. 1998) and drastically reduced recorded cases of malaria (Conway 1972). In spite of their benefits, especially with food production increasing and health management, they have the ability to persist in the environment and accumulate in the food chain (El-Shahawia et al. 2010). They have been banned since 1970s throughout the world for agricultural use according to their potential to elicit toxic effects. Some studies (Velez de la Calle et al. 2001, Oliva et al. 2001) established the relationship between human exposure to organochlorine pesticides and several pathologies such as human infertility, defective births, brain tumors, as well as breast and prostate cancer, etc. In the recent years, there is a growing interest in POPs due to their potential toxicity and adverse impacts on human health (UNEP 2001). The Stockholm convention on POPs in 2001 is an outcome of this growing concern about the persistent organic pollutants including organochlorine pesticides. Although they were banned since 1970s, these chemicals are still routinely found in agricultural soils in some developing countries ( $\mathrm{Fa}$ landysz et al. 2001, Ssebugere et al. 2010). According to some authors, historically contaminated agricultural soils are reservoirs from which old pesticides can disseminate in the environment (Wania and Mackay 1996, Harner et al. 1999). Some of the countries which still use them are, in East Africa: Mozambique, Zambia and Zimbabwe that reported their recent re-introduction of DDT use for malaria control (UNEP 2008). In west Africa, endosulfan which was voluntarily removed in cotton production before 1980s and replaced by pyrethroïds, was re-introduced since 1998 in Benin, 
Burkina Faso, Mali, Senegal and Togo due to resistance developed by pest Helicoverpa armigera (Martin et al. 2005). The environmental and health implications of organochlorine pesticides led to monitor their residue levels at selected sites.

In Togo, pesticides and fertilizers have been increasingly used to boost agricultural productions in small holder-scale farms within the country. In fact, the use of chemical pesticides in Togo dates back to the colonial period to protect coffee, cocoa and cotton crops and in the fight against disease vectors as malaria. The most commonly used pesticides were the organochlorinated compounds (Mawussi 2008). These are generally referred to dichlorodiphenyltrichloroethane (DDT) group, cyclodienes compounds (aldrin, dieldrin, endrin, endosulfan and heptachlor) and isomers of hexachlorocyclohexanes $(\alpha-, \beta-, \gamma-$, $\partial-\mathrm{HCH})$ (Mawussi 2008). In order to protect the population against the harmful effects of pesticides, Togolese government took several decrees to regulate the trade of plant protection products and has signed and or ratified international legal agreements including the Stockholm Convention on POPs signed 23 May 2001 and ratified 22 July 2004, the international code of conduct on the management of pesticides, adopted in June 2013 by Resolution 3/2013 amending the International Code of Conduct on the Distribution and Pesticide Use on 1 November 2002.

The Région des Plateaux in Togo is home to the production of cash crops (coffee, cocoa, cotton) and it is also where synthetic chemical formulation has been and is still being intensively used (Mawussi 2008). In addition to the cultivation of cash crops, the Région de Plateaux is also a major player in the field of market gardening (DSID 2013). This situation makes problematic, not only the possible use of non-registered pesticides on vegetables, but also the possible contamination of agricultural soils by POPs that are used for the production of vegetables. Some studies in west Africa have shown that the use of chemical pesticides in vegetable production has become systematic to optimize yields (Cissé et al. 2003, Adjrah et al. 2013). The vegetable growing in the Région des Plateaux in Togo does not escape this reality. A huge amount of pesticide is being used on crops including vegetables, and their irrational and continued use becomes the reason of their accumulation in agricultural soils. Interestingly, it is commonplace that the regional commercial habits for the provision of pesticides to farmers include the existence of an informal sector that can open the door to the smuggling of banned chemicals like POPs, which farmers can easily access and use for crop protection despite the national regulation that prohibits their import and use (Mawussi 2008).

The aim of this study is to assess the level of agricultural soils contamination by OCPs in vegetable production areas within Région des Plateaux in Togo and to compare it to the maximum residue limits (MRL) set by the Food and Agriculture Organization of the United Nations (FAO).

\section{MATERIALS AND METHODS}

\section{Study area}

The study sites targeted in the framework of this research are selected in Togo (west Africa), in the Région des Plateaux (Fig. 1). The choice was driven by the widespread pesticide usage and the relative time engaged in vegetable production. The sites included Danyime (N 07 $13.452^{\prime}$; E $000^{\circ} 40.041^{\prime}$ ), Todome (N 07²12.461'; E 000 $40.957^{\prime}$ ), Kpime-Seva (N 06 $59.530^{\prime}$; E 000³9.829'), Volove (N 06 $52.766^{\circ}$; E $\left.000^{\circ} 37.087^{\prime}\right)$, Kamina (N 07 $29.663^{\prime}$; E $001^{\circ} 10.409^{\prime}$ ) and Lomnava (N 07 $31.176^{\prime}$; E 001 $07.815^{\prime}$ '). Danyime, Todome, Kpime-Seva and Volove are situated in a tropical rain forest belt broken by heavily forested hills and many streams and rivers. Agricultural crops in this zone include yams, cassava, grains, coffee, cocoa, oil palms, kola nuts, timber and vegetables. On the other hand, Kamina and Lomnava are located in humid savanna plain with low bush. In this zone, cereals dominate (maize, millet, sorghum and rice), but we can also find yams, cassava, groundnut, cowpea, cotton, and vegetables cultivation.

\section{Soil sampling}

Three farmers' plots within each of the six villages were selected. From each one of them, composite soil samples were collected randomly depending on the main vegetable crop grown. Fifty four (54) soil samples in total were collected and analyzed (3 samples per plot $\mathrm{x} 3$ plots $\times 6$ villages $=54$ ). The soil was collected from $0-20 \mathrm{~cm}$ layer using an auger. Soil samples were then air dried and sifted through a $2 \mathrm{~mm}$ sieve and refrigerated at $4{ }^{\circ} \mathrm{C}$ until shipment to Ghana. All samples were transported to the testing laboratory at the Ghana Atomic Energy Commission.

\section{Reagents and solvents}

Analytical grade reagents and solvents were used. They were high-performance liquid chromatography (HPLC) grade hexane, acetone, silica, sodium sulfate and alumina, all from Sigma Aldrich 

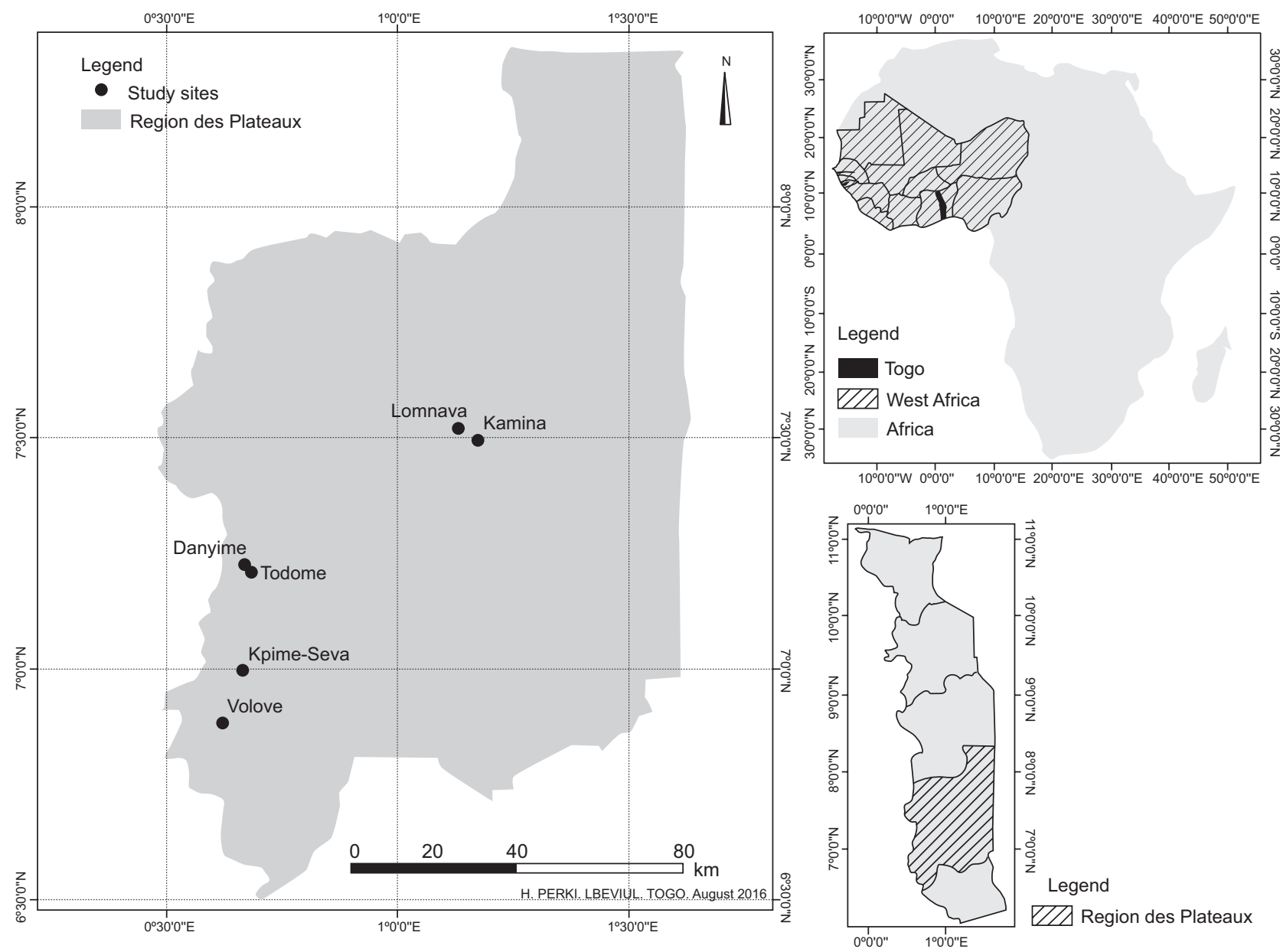

Fig. 1. Map showing the location of the soil samples collection sites

in Germany. The individual reference standards used for the quantification and identification of the organochlorine pesticides were obtained from Cambridge Isotope Laboratories Incorporated, USA. These standard organochlorine pesticides were $\alpha$-endosulfan, $\beta$-endosulfan, endosulfan sulfate, hexachlorocyclohexane $(\alpha-\mathrm{HCH}, \beta-\mathrm{HCH}, \delta-\mathrm{HCH}$ and $\gamma-\mathrm{HCH}$ (lindane)), heptachlor, trans-chlordane and trans-nonachlor. Aldrin, dieldrin, endrin, (collectively called DRINS), the DDT family: dichlorodiphenyltrichloroethane and its metabolites (p,p-DDT, o,p-DDT, p,p-DDE, o,pDDE, p,p-DDD, o,p-DDD) and hexachlorobenzene (HCB) as well as the recovery surrogates standard (2,4,5,6-tetrachlorom-xylene (TCmX) and decachlorobiphenyl (PCB-209)) were also included.

\section{Extraction of pesticide residues from soil samples}

The soil samples were ground into fine particles with clean porcelain mortar and pestle. An aliquot of each sample was weighed $(10.0 \mathrm{~g})$ into the thimble and inserted into the thimble holder of the soxhlet apparatus and made ready for soxhlet extraction. A quantity $(180.0 \mathrm{~mL})$ of appropriate solvent [hexane:acetone $(3: 1 \mathrm{v} / \mathrm{v})$ ] was added to the sample. Pesticide residues were then extracted for $6 \mathrm{~h}$ repeated four times. A solvent (isooctane) was added to the extract as a keeper and concentrated to $1 \mathrm{~mL}$. The cooled elute was concentrated on the rotatory evaporator near to dryness and made ready for clean-up.

\section{Clean up of soil extracts}

Crude extracts contain high proportions of coextracted materials, which may deteriorate the gas chromatography (GC) analysis. Therefore, these co-extracted substances should be removed prior to quantification by GC. For this purpose, the adsorption chromatography was well suited for clean up (Jaouen-Madoulet et al. 2000). In order to elute out organochlorine pesticides from the clean-up 
column, adequate amount of n-hexane, anhydrous sodium sulfate $\left(\mathrm{Na}_{2} \mathrm{SO}_{4}\right)$, alumina $8 \%(100-250$ $\mathrm{mm}$ mesh), hexane-diethyl ether mixture $(85: 15 \mathrm{v} / \mathrm{v})$ and activated silica $(0.063-0.2 \mathrm{~mm} / 70-230$ mesh ASTM) were used. The complete elution of the target compounds was carried out alternatively through alumina and silica columns independently.

\section{Gas chromatography - electron capture detector (GC-ECD) analysis}

Shimadzu GC-2010 equipped with ${ }^{63} \mathrm{Ni}$ electron capture detector (ECD) and split/splitless injector was employed. This gas chromatograph allowed the detection of contaminants even at trace level concentrations (in the lower $\mu \mathrm{g} / \mathrm{kg}$ range) from the matrix to which other detectors do not respond. The temperature of the injector and detector was set at $280{ }^{\circ} \mathrm{C}$ and $300{ }^{\circ} \mathrm{C}$, respectively. A fussed silica ZB-5 (30 m $\times$ $0.25 \mathrm{~mm}, 0.25 \mu \mathrm{m}$ film thickness) was used in combination with the following oven temperature programming: initial temperature $60^{\circ} \mathrm{C}$, held for $1 \mathrm{~min}$, ramp at $30^{\circ} \mathrm{C} / \mathrm{min}$ to $180^{\circ} \mathrm{C}$, held for $3 \mathrm{~min}$, ramp at $3{ }^{\circ} \mathrm{C} / \mathrm{min}$ to $220^{\circ} \mathrm{C}$, held for $3 \mathrm{~min}$, ramp at $10^{\circ} \mathrm{C}$ $/ \mathrm{min}$ to $300{ }^{\circ} \mathrm{C}$. Nitrogen was used as carrier gas at a flow rate of $1.0 \mathrm{~mL} / \mathrm{min}$ and make up the gas of $29 \mathrm{~mL} / \mathrm{min}$. The injection volume of the GC was $1.0 \mu \mathrm{l}$. The residues detected by the GC analysis were confirmed by the analysis of the extract on two other columns of different polarities. The first column was coated with ZB-1 (methyl polysiloxane) connected to ECD and the second column was coated with ZB-17 (50\% phenyl, methyl polysiloxane) and ECD was also used as a detector. The conditions used for these columns were the same as mentioned above.

\section{Quality control and quality assurance}

Quality control and quality assurance were included in the analytical scheme. An aliquot of 10 $\mu \mathrm{g} / \mathrm{mL}$ standard solution containing 21 pesticides was prepared in $99 \% \mathrm{n}$-hexane and stored at $-4{ }^{\circ} \mathrm{C}$. Working mixtures of the standard solutions between 1 to $100 \mathrm{ng} / \mathrm{mL}$ were prepared in $99 \% \mathrm{n}$-hexane. The calibration curves of OCPs were prepared at the concentrations of $1,2,5,10$, and $50 \mathrm{ng} / \mathrm{mL}$. Calibration standards were reestablished with every 10 samples. All measurements were performed within the range of linearity found for each compound. Ten grams of soil from each sample were spiked with $20 \mathrm{ng}$ of TCmX and PCB-209, respectively as recovery surrogates and were Soxhlet-extracted with appropriate solvent [hexane: acetone $(3: 1 \mathrm{v} / \mathrm{v})]$ for $6 \mathrm{~h}$. Recoveries of two surrogates (TCmX and PCB-209) were determined for every sample. The recoveries of the target compounds in spiked samples ranged from $85 \%$ to $104 \%$. DL were also assessed based on the lowest concentrations of the residues in each sample that could be measured at the operating conditions of the $\mathrm{GC}$, which were $0.001 \mu \mathrm{g} / \mathrm{kg}$.

\section{Data handling}

Laboratory analytical results were subjected to analysis of variance (ANOVA) using SAS software, version $9.2,2^{\text {nd }}$ edition of 2010. Separation of the means was performed using Duncan significance test $(\mathrm{p}<0.05)$.

\section{RESULTS AND DISCUSSION}

Of the 21 different organochlorine pesticides analyzed, only aldrin, endosulfan ( $\alpha$-, $\beta$ - and sulfate) and hexachlorocyclohexane $(\mathrm{HCH})$ isomers including $\alpha-\mathrm{HCH}, \beta-\mathrm{HCH}, \delta-\mathrm{HCH}$ and $\gamma-\mathrm{HCH}$ were detected in soil samples. The concentrations of pesticide residues detected in the soil of different areas of study are presented in tables I, II and III. The detected pesticide residues reflected the type of pesticides that have been used in the respective areas, particularly endosulfan which was detected in most of the soil samples in three forms: $\alpha-, \beta$ - and endosulfan sulfate. The ANOVA showed significant differences $(p<0.05)$ between the mean concentrations of organochlorine pesticide residues detected in all the samples of the different farmers' plots at each site and between the plots of different areas as indicated by means data in tables I, II and III. The differences in the concentrations of these pesticide residues in the soil samples may be due to the substantial inter-farm variation in intensive use of pesticide as well as the differences in their degradation rate (Owusu-Boateng and Amuzu 2013).

\section{Aldrin}

Aldrin residues were detected in very low concentrations as compared to other organochlorine pesticides. The results indicate higher amounts of endosulfan and $\mathrm{HCH}$ isomers as compared to aldrin. Differences in the concentration of aldrin residues in soils among the sampled areas were significant $(\mathrm{p}<$ 0.05 ). Aldrin was detected in various levels from 0.04 $\pm 0.01 \mu \mathrm{g} / \mathrm{kg}$ to $0.93 \pm 0.03 \mu \mathrm{g} / \mathrm{kg}$ (Table I, II and III) in the samples. The accumulation of aldrin in soil samples analyzed during the present study, was probably originated from its historical use because the areas of study were located in old coffee, cocoa, and cotton production areas where different formulations 
TABLE I. MEAN OF PESTICIDE RESIDUES CONCENTRATIONS $(\mu \mathrm{g} / \mathrm{kg})$ IN THE SOIL OF DANYI-APÉYÉMÉ SECTOR

\begin{tabular}{|c|c|c|c|c|c|c|c|}
\hline \multirow{2}{*}{$\begin{array}{l}\text { Localities } \\
\text { Pesticides }\end{array}$} & \multicolumn{3}{|c|}{ Danyimé } & \multicolumn{3}{|c|}{ Todomé } & \multirow{2}{*}{$\begin{array}{c}\text { FAO } 2000 \\
\text { RV }\end{array}$} \\
\hline & Plot 1 & Plot 2 & Plot 3 & Plot 1 & Plot 2 & Plot 3 & \\
\hline$\alpha-\mathrm{HCH}^{*}$ & $0.17 \pm 0.05^{\mathrm{a}}$ & $0.05 \pm 0.12^{\mathrm{b}}$ & $0.06 \pm 0.02^{b}$ & $0.14 \pm 0.06^{\mathrm{a}}$ & DL & $0.16 \pm 0.13^{\mathrm{a}}$ & 100 \\
\hline$\beta-\mathrm{HCH}$ & $4.04 \pm 0.09^{c}$ & DL & DL & $9.73 \pm 0.12^{\mathrm{a}}$ & $7.94 \pm 0.10^{\mathrm{b}}$ & DL & 200 \\
\hline$\gamma$-HCH & $4.22 \pm 0.04^{\mathrm{a}}$ & $1.07 \pm 0.01^{\mathrm{c}}$ & $2.34 \pm 0.17^{\mathrm{b}}$ & $4.27 \pm 0.61^{\mathrm{a}}$ & DL & $1.00 \pm 0.10^{\mathrm{c}}$ & - \\
\hline$\delta-\mathrm{HCH}$ & DL & $0.04 \pm 0.01^{\mathrm{b}}$ & $2.74 \pm 0.05^{\mathrm{a}}$ & DL & $2.68 \pm 0.04^{\mathrm{a}}$ & $2.72 \pm 0.06^{\mathrm{a}}$ & - \\
\hline$\Sigma \mathrm{HCH}$ & $8.43 \pm 0.06^{\mathrm{c}}$ & $1.16 \pm 0.05^{\mathrm{f}}$ & $5.14 \pm 0.08^{\mathrm{d}}$ & $14.14 \pm 0.26^{\mathrm{a}}$ & $10.62 \pm 0.07^{b}$ & $3.88 \pm 0.09^{\mathrm{e}}$ & - \\
\hline$\alpha$-endosulfan & DL & $1.00 \pm 0.05^{\mathrm{a}}$ & $0.2 \pm 0.05^{\mathrm{b}}$ & DL & DL & $0.18 \pm 0.04^{\mathrm{b}}$ & - \\
\hline$\beta$-endosulfan & $0.81 \pm 0.01^{\mathrm{c}}$ & $3.00 \pm 0.09^{\mathrm{a}}$ & $2.07 \pm 0.35^{\mathrm{b}}$ & $2.06 \pm 0.42^{\mathrm{b}}$ & DL & $3.07 \pm 0.17^{\mathrm{a}}$ & - \\
\hline Endo sulfate & DL & $0.13 \pm 0.01$ & DL & DL & DL & DL & - \\
\hline$\Sigma$ endosulfan & $0.81 \pm 0.01^{\mathrm{d}}$ & $4.13 \pm 0.05^{\mathrm{a}}$ & $2.27 \pm 0.20^{\mathrm{c}}$ & $2.06 \pm 0.42^{\mathrm{c}}$ & DL & $3.25 \pm 0.10^{\mathrm{b}}$ & - \\
\hline Aldrin & $0.09 \pm 0.06^{\mathrm{c}}$ & DL & $0.3 \pm 0.15^{\mathrm{a}}$ & DL & $0.18 \pm 0.03^{\mathrm{b}}$ & DL & - \\
\hline $\mathrm{DDE}^{* *}$ & DL & DL & DL & DL & DL & DL & 8000 \\
\hline Endrin & DL & DL & DL & DL & DL & DL & 200 \\
\hline
\end{tabular}

Mean values within the rows followed by the same alphabet letters are not significantly different $(\mathrm{p}<0.05)$ while using ANOVA and test of Duncan. DL = below instrument detection limit $(0.001 \mu \mathrm{g} / \mathrm{kg})$. Notes: all values in the table are Mean \pm Standard deviation of three replicates. RV (reference values): data indicate maximum permissible concentrations exposure level for contaminated soils in which vegetables and tubers are grown $[\mu \mathrm{g} / \mathrm{kg}$ soil $]$ (FAO 2000). (* $\mathrm{HCH}=$ Hexachlorocyclohexane, ** DDE $=$ Dichlorodiphenyldichloroethylene).

TABLE II. MEAN OF PESTICIDE RESIDUES CONCENTRATIONS $(\mu \mathrm{g} / \mathrm{kg})$ IN THE SOIL OF KPALIMÉ SECTOR

\begin{tabular}{|c|c|c|c|c|c|c|c|}
\hline \multirow{2}{*}{$\begin{array}{l}\text { Localities } \\
\text { pesticides }\end{array}$} & \multicolumn{3}{|c|}{ Kpimé-Séva } & \multicolumn{3}{|c|}{ Volové } & \multirow{2}{*}{$\begin{array}{c}\text { FAO } 2000 \\
\text { RV }\end{array}$} \\
\hline & Plot 1 & Plot 2 & Plot 3 & Plot 1 & Plot 2 & Plot 3 & \\
\hline$\alpha-\mathrm{HCH}^{*}$ & $0.09 \pm 0.01^{\mathrm{d}}$ & $0.25 \pm 0.02^{\mathrm{c}}$ & DL & $0.52 \pm 0.08^{b}$ & $0.89 \pm 0.07^{\mathrm{a}}$ & $0.19 \pm 0.03^{\mathrm{c}}$ & 100 \\
\hline$\beta-\mathrm{HCH}$ & $13.30 \pm 0.24^{\mathrm{a}}$ & DL & $6.33 \pm 0.43^{\mathrm{c}}$ & $8.10 \pm 0.2^{b}$ & $3.16 \pm 0.64^{d}$ & $8.23 \pm 0.03^{b}$ & 200 \\
\hline$\gamma-\mathrm{HCH}$ & $1.81 \pm 0.04^{\mathrm{b}}$ & $1.56 \pm 0.1^{\mathrm{b}}$ & $2.23 \pm 0.06^{\mathrm{a}}$ & $\mathrm{DL}$ & $1.61 \pm 0.03^{\mathrm{b}}$ & $1.6 \pm 0.07^{\mathrm{b}}$ & - \\
\hline$\delta-\mathrm{HCH}$ & $\mathrm{DL}$ & $0.37 \pm 0.04^{\mathrm{a}}$ & $0.11 \pm 0.08^{b}$ & DL & DL & DL & - \\
\hline$\Sigma \mathrm{HCH}$ & $15.2 \pm 0.09^{\mathrm{a}}$ & $2.18 \pm 0.05^{\mathrm{e}}$ & $8.67 \pm 0.19^{c}$ & $8.62 \pm 0.14^{\mathrm{c}}$ & $5.66 \pm 0.25^{\mathrm{d}}$ & $10.02 \pm 0.04^{\mathrm{b}}$ & - \\
\hline$\alpha$-endosulfan & $1.66 \pm 0.18^{\mathrm{a}}$ & DL & $1.88 \pm 0.41^{\mathrm{a}}$ & $0.3 \pm 0.02^{\mathrm{b}}$ & DL & $0.29 \pm 0.24^{\mathrm{b}}$ & - \\
\hline$\beta$-endosulfan & $\mathrm{DL}$ & DL & $3.19 \pm 0.38^{\mathrm{a}}$ & $2.86 \pm 0.27^{\mathrm{b}}$ & $1.24 \pm 0.33^{\mathrm{c}}$ & $2.89 \pm 0.61^{\mathrm{b}}$ & - \\
\hline Endo sulfate & DL & $0.09 \pm 0.02^{\mathrm{b}}$ & DL & DL & $0.4 \pm 0.01^{\mathrm{a}}$ & DL & - \\
\hline$\Sigma$ endosulfan & $1.66 \pm 0.18^{\mathrm{c}}$ & $0.09 \pm 0.02^{\mathrm{d}}$ & $5.07 \pm 0.39^{\mathrm{a}}$ & $3.16 \pm 0.14^{\mathrm{b}}$ & $1.64 \pm 0.17^{\mathrm{c}}$ & $3.18 \pm 0.42^{\mathrm{b}}$ & - \\
\hline Aldrin & $0.3 \pm 0.01^{\mathrm{a}}$ & DL & $0.04 \pm 0.02^{\mathrm{b}}$ & DL & DL & DL & - \\
\hline $\mathrm{DDE}^{* *}$ & DL & DL & DL & DL & DL & DL & 8000 \\
\hline Endrin & DL & DL & DL & DL & DL & DL & 200 \\
\hline
\end{tabular}

Mean values within the rows followed by the same alphabet letters are not significantly different $(\mathrm{p}<0.05)$ while using ANOVA and test of Duncan. DL = below instrument detection limit $(0.001 \mu \mathrm{g} / \mathrm{kg})$. Notes: all values in table are Mean \pm Standard deviation of three replicates. RV (reference values): data indicate maximum permissible concentrations exposure level for contaminated soils in which vegetables and tubers are grown $[\mu \mathrm{g} / \mathrm{kg}$ soil $](\mathrm{FAO} 2000)$. $(* \mathrm{HCH}=$ Hexachlorocyclohexane, $* *$ DDE $=$ Dichlorodiphenyldichloroethylene)

of organochlorine pesticides (DDT, dieldrin, aldrin, endrin, endosulfan, lindane etc.) were extensively used in the past (Mawussi 2008). These findings were in a lower position than the findings of the study carried out by Okoya et al. (2013) on soil samples of some cocoa plantations in Ondo State in Nigeria (west Africa) where aldrin concentration in soil ranged from $0.01 \pm 0.01 \mu \mathrm{g} / \mathrm{kg}$ to $5.06 \pm 1.05 \mu \mathrm{g} / \mathrm{kg}$ (Fig. 2).

\section{Endosulfan}

Endosulfan isomers ( $\alpha$ - and $\beta$-) and the metabolite endosulfan sulfate were detected in soils samples from the farmers' plots studied. It has been registered in Togo since 1998 for exclusive use on cotton cultivation against Helicoverpa armigera which resists synthetic pyrethroid and organophosphorous insecticides (Mawussi 2008). Based on the ANOVA and Duncan tests, the mean concentrations of endosulfan 
TABLE III. MEAN OF PESTICIDE RESIDUES CONCENTRATIONS $(\mu \mathrm{g} / \mathrm{kg})$ IN THE SOIL OF ATAKPAMÉ SECTOR

\begin{tabular}{|c|c|c|c|c|c|c|c|}
\hline \multirow{2}{*}{$\begin{array}{l}\text { Localities } \\
\text { Pesticides }\end{array}$} & \multicolumn{3}{|c|}{ Kamina } & \multicolumn{3}{|c|}{ Lomnava } & \multirow{2}{*}{$\begin{array}{c}\text { FAO } 2000 \\
\text { RV }\end{array}$} \\
\hline & Plot 1 & Plot 2 & Plot 3 & Plot 1 & Plot 2 & Plot 3 & \\
\hline$\alpha-\mathrm{HCH}^{*}$ & $0.41 \pm 0.15^{\mathrm{b}}$ & $0.38 \pm 0.09^{\mathrm{b}}$ & $0.39 \pm 0.06^{\mathrm{b}}$ & $0.5 \pm 0.03^{\mathrm{a}}$ & DL & $0.16 \pm 0.08^{c}$ & 100 \\
\hline$\beta-\mathrm{HCH}$ & $10.67 \pm 0.10^{\mathrm{c}}$ & $14.6 \pm 0.12^{\mathrm{a}}$ & $2.06 \pm 0.03^{\mathrm{e}}$ & $12.16 \pm 0.18^{b}$ & $10.1 \pm 0.06^{\mathrm{c}}$ & $7.10 \pm 0.07^{\mathrm{d}}$ & 200 \\
\hline$\gamma-\mathrm{HCH}$ & $1.34 \pm 0.02^{\mathrm{b}}$ & $3.00 \pm 0.13^{\mathrm{a}}$ & $0.8 \pm 0.12^{\mathrm{c}}$ & $0.98 \pm 0.01^{\mathrm{c}}$ & DL & $1.40 \pm 0.01^{\mathrm{b}}$ & - \\
\hline$\delta-\mathrm{HCH}$ & $2.92 \pm 0.05^{\mathrm{a}}$ & DL & DL & $0.3 \pm 0.06^{\mathrm{b}}$ & DL & $0.28 \pm 0.01^{b}$ & - \\
\hline$\Sigma \mathrm{HCH}$ & $15.34 \pm 0.08^{b}$ & $17.98 \pm 0.11^{\mathrm{a}}$ & $3.25 \pm 0.07^{\mathrm{f}}$ & $13.94 \pm 0.07^{\mathrm{c}}$ & $10.1 \pm 0.06^{\mathrm{d}}$ & $8.94 \pm 0.04^{\mathrm{e}}$ & - \\
\hline$\alpha$-endosulfan & $0.58 \pm 0.02^{\mathrm{b}}$ & $0.23 \pm 0.01^{\mathrm{c}}$ & $0.29 \pm 0.02^{\mathrm{c}}$ & $0.26 \pm 0.01^{\mathrm{c}}$ & DL & $1.75 \pm 0.27^{\mathrm{a}}$ & - \\
\hline$\beta$-endosulfan & $3.87 \pm 0.19^{\mathrm{a}}$ & $2.23 \pm 0.20^{\mathrm{b}}$ & $1.83 \pm 0.02^{\mathrm{c}}$ & DL & $1.03 \pm 0.04^{\mathrm{d}}$ & $1.02 \pm 0.11^{\mathrm{d}}$ & - \\
\hline Endo sulfate & DL & DL & DL & $0.21 \pm 0.01^{\mathrm{a}}$ & $0.19 \pm 0.04^{\mathrm{a}}$ & DL & - \\
\hline$\Sigma$ endosulfan & $4.45 \pm 0.10^{\mathrm{a}}$ & $2.46 \pm 0.10^{\mathrm{b}}$ & $2.12 \pm 0.02^{\mathrm{b}}$ & $0.47 \pm 0.01^{\mathrm{d}}$ & $1.22 \pm 0.04^{\mathrm{c}}$ & $2.77 \pm 0.19^{\mathrm{b}}$ & - \\
\hline Aldrin & DL & $0.93 \pm 0.03^{\mathrm{a}}$ & DL & DL & $0.06 \pm 0.01^{\mathrm{c}}$ & $0.15 \pm 0.01^{b}$ & - \\
\hline $\mathrm{DDE}^{* *}$ & DL & DL & DL & DL & DL & DL & 8000 \\
\hline Endrin & DL & DL & DL & DL & DL & DL & 200 \\
\hline
\end{tabular}

Mean values within the rows followed by the same alphabet letters are not significantly different $(\mathrm{p}<0.05)$ while using ANOVA and test of Duncan. DL = below instrument detection limit $(0.001 \mu \mathrm{g} / \mathrm{kg})$. Notes: all values in table are Mean \pm Standard deviation of three replicates. RV (reference values): data indicate maximum permissible concentrations exposure level for contaminated soils in which vegetables and tubers are grown $[\mu \mathrm{g} / \mathrm{kg}$ soil $]$ (FAO 2000). $(* \mathrm{HCH}$ : Hexachlorocyclohexane, $* *$ DDE $=$ Dichlorodiphenyldichloroethylene).

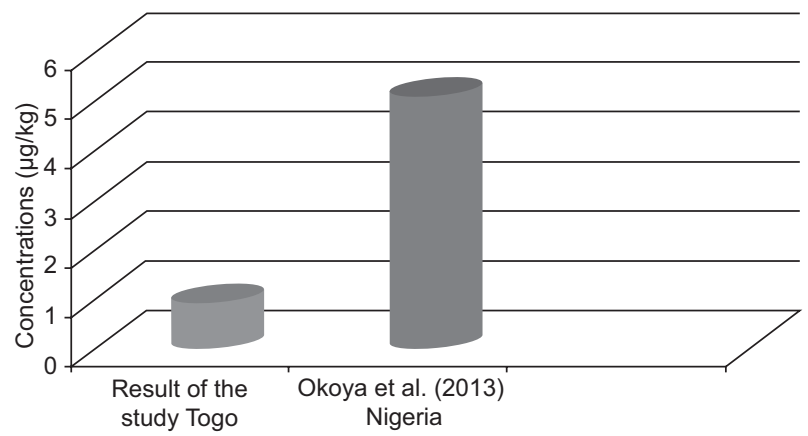

Fig. 2. Mean of the highest values of aldrin concentrations $(\mu \mathrm{g} /$ $\mathrm{kg}$ ) in soil of present study as compared with those of previous scholars

$(\alpha-, \beta$ - and sulfate) residues in soil samples showed significant differences $(\mathrm{p}<0.05)$ in different study areas (Table I, II and III). The highest value of 3.87 \pm $0.19 \mu \mathrm{g} / \mathrm{kg}$ was observed with $\beta$-endosulfan at Kamina area (Table III), while the lowest concentration of $0.09 \pm 0.02 \mu \mathrm{g} / \mathrm{kg}$ was registered for endosulfan sulfate in Kpimé-Séva (Table II). The $\alpha$-endosulfan and $\beta$-endosulfan isomers were detected in soil samples with the levels ranging from $0.18 \pm 0.04$ to $1.88 \pm$ $0.41 \mu \mathrm{g} / \mathrm{kg}$ and from $0.81 \pm 0.01$ to $3.87 \pm 0.19 \mu \mathrm{g} / \mathrm{kg}$, respectively. Comparatively, the concentration of $\beta$-isomer was higher than that of $\alpha$-isomer. This is explained by the quicker degradation of the $\alpha$-isomer in the soil (Kathpal et al. 1997). $\beta$-endosulfan is found to be degrading in the soil more slowly than the $\alpha$-isomer with the range of half-lives reported as: $\alpha$-isomer 7-75 days and $\beta$-isomer 33-376 days (Weber et al. 2010). In addition, $\beta$-Endosulfan is less soluble in water and more strongly bound to the soil particles than $\alpha$-isomer (Beyers et al.1965). Thus, $\alpha$-isomer may be carried by run off to the aquatic environment. The findings of the present study were comparable to those reported in Ondo State in Nigeria (west Africa) where $\alpha$-endosulfan and $\beta$-endosulfan were found in the soil of some cocoa plantations with the concentration ranges of $0.01 \pm 0.01-0.05 \pm 0.01 \mu \mathrm{g} / \mathrm{kg}$ and $0.01 \pm 0.01-9.15 \pm 0.06 \mu \mathrm{g} / \mathrm{kg}$ respectively (Okoya et al. 2013; Fig. 3). Contrary to our findings, the higher residues have been reported by Dem et al. (2007) in Mali (west Africa) where $\alpha$-endosulfan and $\beta$-endosulfan were found in the agricultural soil of cotton growing areas with concentrations of $10 \mu \mathrm{g} /$ $\mathrm{kg}$ and $37 \mu \mathrm{g} / \mathrm{kg}$, respectively (Fig. 3). Endosulfan sulfate is the major degrading product of endosulfan. It is known to be as toxic as the parent compound. It was detected below the limit of detection in most of the soil samples and with concentration ranging from $0.09 \pm 0.02$ to $0.4 \pm 0.01 \mu \mathrm{g} / \mathrm{kg}$.

\section{HCH isomers}

Statistical analysis of the data showed significant differences between concentration values of $\mathrm{HCH}$ isomers: $\alpha-\mathrm{HCH}, \beta-\mathrm{HCH}, \gamma-\mathrm{HCH}$ and $\delta-\mathrm{HCH}$ in soil samples within the farmers' plots of each area and between different areas $(p<0.05)$ (Tables I, II and III). Their highest concentration was found in soil sample collected from Kamina area with $\beta-\mathrm{HCH}$ 


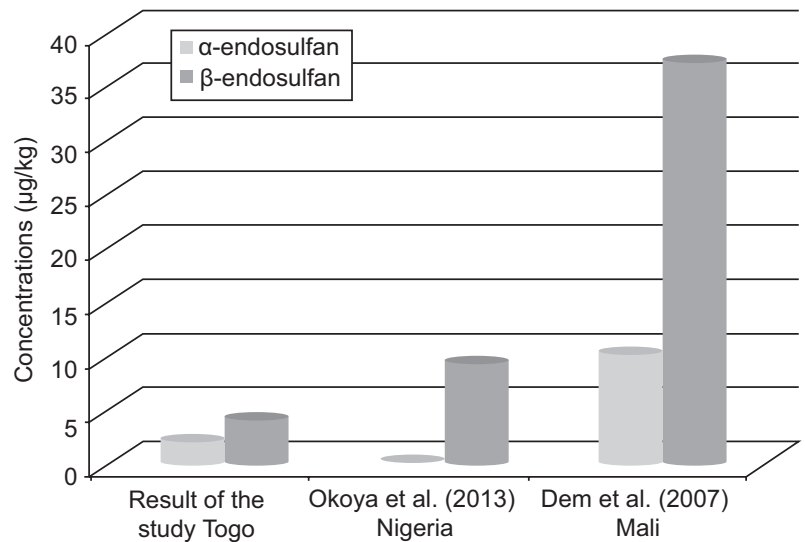

Fig. 3. Mean of the highest values of $\alpha$ - and $\beta$-endosulfan concentrations $(\mu \mathrm{g} / \mathrm{kg})$ in the soil of present study as compared with those of previous scholars

$(14.6 \pm 0.12 \mu \mathrm{g} / \mathrm{kg}$; Table III), while their lowest amount was detected in soil sampled in Danyimé area with $\delta$-HCH $(0.04 \pm 0.01 \mu \mathrm{g} / \mathrm{kg}$; Table I $)$. It stems from this study that $\beta-\mathrm{HCH}$ was detected in the highest amounts compared to other three isomers $(\alpha-, \gamma-$ and $\delta-\mathrm{HCH})$. This trend is supported by the fact that $\beta-\mathrm{HCH}$ is known to be more persistent than the other isomers and dissipates slowly due to a low vapor pressure (Zhang et al. 2006). The total concentrations of $\mathrm{HCHs}$ (sum of $\alpha-\mathrm{HCH}, \beta-\mathrm{HCH}, \delta-\mathrm{HCH}$ and $\gamma-\mathrm{HCH}$ ) in surface soil in the present study were in the range of $1.16 \pm 0.05-17.98 \pm 0.13 \mu \mathrm{g} / \mathrm{kg}$. In comparison with similar studies carried out in other countries, the results of the present study show that
$\mathrm{HCH}$ isomers residues in soil occurred at levels comparable to, or in some cases higher than those of the previous reports (Kishimba and Mihale 2004).

$\mathrm{HCH}$ is available in two formulations: technical $\mathrm{HCH}$ and lindane. Technical $\mathrm{HCH}$ contains isomers in the following percentage: $\alpha-\mathrm{HCH}(60-70 \%), \beta-\mathrm{HCH}$ (5-12\%), $\gamma$-HCH (10-15\%), $\delta$-HCH (6-10\%), while lindane contains $99 \%$ of $\gamma-\mathrm{HCH}$ (Qui et al. 2004). The ratio $\alpha-\mathrm{HCH} / \gamma-\mathrm{HCH}$ is used as an indicator of contaminant source age. Ratios $\alpha-\gamma$ - around $\geq$ 3 indicate $\mathrm{HCH}$ input from technical $\mathrm{HCH}$ application, and low ratios $(\alpha-\mathrm{HCH} / \gamma-\mathrm{HCH}<1)$ indicate possible use of lindane (Willet et al. 1998). In the case of the present study, ratios $\alpha-\gamma$ - were between 0.02 and 0.55 (Table IV). These values are below 1 and reflect a historic use of lindane in the areas of study. Of the $\mathrm{HCH}$ isomers, only $\gamma-\mathrm{HCH}$ (lindane) has insecticidal properties and its use was widespread in the past on cotton, coffee, and cocoa against major pests (Mawussi 2008).

\section{Comparison of pesticide residue levels in studied soils to maximum residue limits (MRL) of FAO (2000)}

The maximum permissible concentrations of organochlorine pesticide residues in contaminated soils in which vegetables and tubers are cultivated, are $8000 \mu \mathrm{g} / \mathrm{kg}$ for DDE, $200 \mu \mathrm{g} / \mathrm{kg}$ for endrin and $\beta$-HCH and $100 \mu \mathrm{g} / \mathrm{kg}$ for $\alpha-\mathrm{HCH}$ (FAO 2000). The concentrations of isomers $\alpha-\mathrm{HCH}(<0.001 \mu \mathrm{g} / \mathrm{kg}$ to $0.89 \pm 0.07 \mu \mathrm{g} / \mathrm{kg})$ and $\beta-\mathrm{HCH}(<0.001 \mu \mathrm{g} / \mathrm{kg}$ to

TABLE IV. RATIOS $\alpha$-HEXACHLOROCYCLOHEXANE/ $\gamma$-HEXACHLOROCYCLOHEXANE $(\alpha-\mathrm{HCH} / \gamma-\mathrm{HCH}) \mathrm{IN}$ THE SOILS STUDIED

\begin{tabular}{|c|c|c|c|c|c|c|}
\hline & \multicolumn{3}{|c|}{ Danyimé } & \multicolumn{3}{|c|}{ Todomé } \\
\hline & Plot 1 & Plot 2 & Plot 3 & Plot 1 & Plot 2 & Plot 3 \\
\hline$\alpha-\mathrm{HCH}$ & 0.17 & 0.05 & 0.06 & 0.14 & DL & 0.16 \\
\hline$\gamma-\mathrm{HCH}$ & 4.22 & 1.07 & 2.34 & 4.27 & DL & 1.00 \\
\hline \multirow[t]{3}{*}{$\alpha-/ \gamma-$} & 0.04 & 0.04 & 0.02 & 0.03 & - & 0.16 \\
\hline & \multicolumn{3}{|c|}{ Kpimé-Séva } & \multicolumn{3}{|c|}{ Volové } \\
\hline & Plot 1 & Plot 2 & Plot 3 & Plot 1 & Plot 2 & Plot 3 \\
\hline$\alpha-\mathrm{HCH}$ & 0.09 & 0.25 & DL & 0.52 & 0.89 & 0.19 \\
\hline$\gamma-\mathrm{HCH}$ & 1.81 & 1.56 & 2.23 & DL & 1.61 & 1.6 \\
\hline \multirow[t]{3}{*}{$\alpha-/ \gamma-$} & 0.05 & 0.16 & - & - & 0.55 & 0.12 \\
\hline & \multicolumn{3}{|c|}{ Kamina } & \multicolumn{3}{|c|}{ Lomnava } \\
\hline & Plot 1 & Plot 2 & Plot 3 & Plot 1 & Plot 2 & Plot 3 \\
\hline$\alpha-\mathrm{HCH}$ & 0.41 & 0.38 & 0.39 & 0.5 & DL & 0.16 \\
\hline$\gamma-\mathrm{HCH}$ & 1.34 & 3.00 & 0.8 & 0.98 & DL & 1.40 \\
\hline$\alpha-/ \gamma-$ & 0.31 & 0.13 & 0.49 & 0.51 & - & 0.11 \\
\hline
\end{tabular}


$14.6 \pm 0.12 \mu \mathrm{g} / \mathrm{kg}$ ) found in studied soils were significantly lower than the FAO permissible exposure level for contaminated soils $100 \mu \mathrm{g} / \mathrm{kg}$ and $200 \mu \mathrm{g} /$ $\mathrm{kg}$, respectively (Tables I, II and III). The maximum permissible concentrations of organochlorine pesticides in contaminated soil varied from $100 \mu \mathrm{g} / \mathrm{kg}$ to $8000 \mu \mathrm{g} / \mathrm{kg}$ (FAO 2000). For this reason, all other pesticide residue levels including aldrin, endosulfan and isomers $\gamma-\mathrm{HCH}, \delta-\mathrm{HCH}$ recorded in the studied soils were highly below permissible maximum residue limits recommended by FAO (2000).

\section{CONCLUSION}

The present investigation assessed the level of agricultural soil contamination by some organochlorine pesticides in vegetable growing areas within Région des Plateaux in Togo. The analysis of the soil samples from various locations revealed the presence of aldrin, endosulfan $(\alpha-, \beta$ - and sulfate) and $\mathrm{HCH}$ isomers including $\alpha-\mathrm{HCH}, \beta-\mathrm{HCH}, \gamma-\mathrm{HCH}$ and $\delta-\mathrm{HCH}$ in variable concentrations. The presence of these compounds in studied soils may be attributed to their persistence due to past agricultural uses or to their illegal application in this region where coffee, cocoa, and cotton are being produced. The concentrations of pesticide residues in the studied soils were found to be significantly lower than the maximum permissible concentrations in contaminated soils in which vegetables and tubers are grown as recommended by FAO. Despite the low level of contamination in the studied soils, the best environmental management in the vegetable production area requires the regular monitoring of soil contamination level in this region of Togo.

\section{REFERENCES}

Adjrah Y., Dovlo A., Karou S.D., Eklu-Gadegbeku K., Agbonon A., de Souza C. and Gbeassor M. (2013). Survey of pesticide application on vegetables in the Littoral area of Togo. Ann. Agric. Environ. Med. 20, 715-720.

Beyers R.A., Woodham D.W. and Bowman M.C.G. (1965). Residues on coastal Bermuda grass, trash and soil treated with endosulphan. J. Econ. Entomol. 58, 160-171. DOI: $10.1093 / \mathrm{jee} / 58.1 .160$

Cissé I., Tandia A.A., Fall S.T. and Diop E-H.S. (2003). Usage incontrôlé des pesticides en agriculture périurbaine: cas zone des Niayes au Sénégal. Cah. Agric. $12,181-186$.
Conway G.R. (1972). Ecological aspects of pest control in Malaysia. In: The careless technology: Ecological aspect of international development (M.T. Farvar and J.P. Milton, Eds.). Natural History Press, Garden City, New York, EUA, pp. 567-488.

DSID (2013). Recensement National de l'Agriculture 2011 - 2014: Aperçu Général de l'Agriculture Togolaise à travers le pré-recensement. Direction des Statistiques agricoles, de l'Informatique et de la Documentation Ministère de l'Agriculture, de l'Elevage et de la Pêche $1,122 \mathrm{pp}$.

Dem S.B., Cobb J.M. and Mullins D.E. (2007). Pesticide residues in soil and water from four cotton growing areas of Mali, West Africa. J. Agric. Food. Environ. Sci. 1, 1-12.

El-Shahawia M.S., Hamza A., Bashammakh A.S. and AlSaggaf W.T. (2010). An overview on the accumulation, distribution, transformations, toxicity and analytical methods for the monitoring of persistent organic pollutants. Talanta 80, 1587-1597.

DOI: 10.1016/j.talanta.2009.09.055

Falandysz J., Brudnowska B. and Kawano M. (2001). Polychlorinated biphenyls and organochlorine pesticides in soils from the southern part of Poland. Arch. Environ. Contam. Toxicol. 40, 173-178.

DOI: $10.1007 / \mathrm{s} 002440010160$

FAO (2000). Assessing soil contamination A reference manual. Food and Agriculture Organization of the United Nations. Pesticide disposal series 8 Rome, Italy, $232 \mathrm{pp}$.

Harner T., Wideman J.L., Jantunen L.M.M., Bidleman T.F. and Parkhurst W.J. (1999). Residues of organochlorine pesticides in Alabama soils. Environ. Pollut. 106, 323332. DOI: 10.1016/S0269-7491(99)00110-4

Jaouen-Madoulet A., Abarnou A., Le Guellec A.-M., Loizeau V. and Leboulenger F. (2000). Validation of an analytical procedure for polychlorinated biphenyls, coplanar polychlorinated biphenyls and polycyclic aromatic hydrocarbons in environmental samples. J. Chromatogr. A. 886, 153-173.

DOI: 10.1016/S0021-9673(00)00422-2

Kathpal T.S., Singh A., Dhankhar J.S. and Singh G. (1997). Fate of endosulfan in cotton soil under subtropical conditions of northern India. Pestic. Sci. 50, 21-27. DOI: 10.1002/(SICI)1096-9063(199705)50:1<21::AIDPS550>3.0.CO;2-N

Kishimba M.A. and Mihale M.J. (2004). Levels of pesticide residues and metabolites in soil at Vikuge farm, Kibaha district, Tanzania - a classic case of soil contamination by obsolete pesticides. Tanz. J. Sci. 30, 77-86. DOI: $10.4314 /$ tjs.v30i2.18402

Martin T., Ochou O.G., Djihinto A., Traore D., Togola M., Vassal J.M., Vaissayre M. and Fournier D. (2005). 
Controlling an insecticide-resistant bollworm in West Africa. Agric. Ecosyst. Environ. 107, 409-411.

DOI: $10.1016 /$ j.agee.2004.11.006

Mawussi G. (2008). Bilan environnemental de l'utilisation de pesticides organochlorés dans les cultures de coton, café et cacao au Togo et recherche d'alternatives par l'évaluation du pouvoir insecticide d'extraits de plantes locales contre le scolyte du café (Hypothenemus hampei Ferrari). Thèse de doctorat. Université de Toulouse, France, 207 pp.

Okoya A.A., Torto N., Ogunfowokan A.O. and Asubiojo O.I. (2013). Organochlorine (OC) pesticide residues in soils of major cocoa plantations in Ondo State, Southwestern Nigeria. Afr. J. Agric. Res. 8, 3842-3848. DOI: $10.5897 / A J A R 12.1605$

Oliva A, Spira A. and Multigner L. (2001). Contribution of environmental factors to the risk of male infertility.

Hum. Reprod. 16, 1768-1776.

DOI: $10.1093 /$ humrep/16.8.1768

Owusu-Boateng G. and Amuzu K.K. (2013). Levels of organochlorine pesticides residue in cabbage cultivated in farms along River Oyansia, Accra-Ghana. Am. J. Sci. Ind. Res. 4, 489-498.

DOI: 10.5251/ajsir.2013.4.5.489.498

Ssebugere P., Wasswa J., Mbabazi J., Nyanzi S.A., Kiremire B.T. and Marco J.A.M. (2010). Organochlorine pesticides in soils from South-western Uganda. Chemosphere 78, 1250-1255.

DOI: $10.1016 /$ j.chemosphere.2009.12.039

UNEP (2001). Final act of the conference of plenipotentiaries on the Stockholm Convention on Persistant Organic Pollutants. United Nations Environmental Program. Geneva, Switzerland, Stockholm, 22-23 May 2001, 44 pp.
UNEP (2008). Global status of DDT and its alternatives for use in vector control to prevent disease. Stockholm Convention on Persistent Organic Pollutants Stakeholders' Meeting to review the interim report for the establishment of a global partnership to develop alternatives to DDT. United Nations Environmental Program. Geneva, Switzerland. 3-5 November 2008. $31 \mathrm{pp}$.

Velez de la Calle J.F., Rachou E., le Martelot M.T., Ducot B., Multigner L. and Thonneau P.F. (2001). Male infertility risk factors in a French military population. Hum. Reprod. 16, 481-486. DOI: 10.1093/humrep/16.3.481

Wania F. and Mackay D. (1996). Tracking the distribution of persistent organic pollutants. Environ. Sci. Technol. 30, 390-396. DOI: 10.1021/es962399q

Weber J., Halsall C.J., Muir D., Teixeira C., Small J., Solomon K., Hermansond M., Hung H. and Bidleman T. (2010). Endosulfan, a global pesticide: A review of its fate in the environment and occurrence in the Arctic. Sci. Total Environ. 408, 2966-2984. DOI: $10.1016 /$ j.scitotenv.2009.10.077

Willett K.L., Ulrich E.M. and Hites S.A. (1998). Differential toxicity and environmental fates of Hexachlorocyclohexane isomers. Environ. Sci. Technol. 32, 2197-2207. DOI: 10.1021/es9708530

Zhang H.B., Luo Y.M., Zhao Q.G., Wong M.H. and Zhang G.L. (2006). Residues of organochlorine pesticides in Hong Kong soils. Chemosphere 63, 633-641. DOI: 10.1016/j.chemosphere.2005.08.006 